Article

\title{
Sunscreen Based on Dicarboxylic Acid Salts Applications to Blueberries (Vaccinium corymbosum L.) Plants: Effects on Water Stress Tolerance and Productivity
}

\author{
Gastón Gutiérrez-Gamboa ${ }^{1}$ (D), Mario Guerrero-Méndez ${ }^{2}$, Miguel Araya-Alman ${ }^{3}$, Nicolás Verdugo-Vásquez ${ }^{4}$ (D), \\ Héctor Valdés-Gómez ${ }^{5, *}$ and César Acevedo-Opazo ${ }^{6, *}$
}

check for updates

Citation: Gutiérrez-Gamboa, G.; Guerrero-Méndez, M.; Araya-Alman, M.; Verdugo-Vásquez, N.;

Valdés-Gómez, H.; Acevedo-Opazo, C. Sunscreen Based on Dicarboxylic Acid Salts Applications to Blueberries (Vaccinium corymbosum L.) Plants: Effects on Water Stress Tolerance and Productivity. Horticulturae 2022, 8, 95. https://doi.org/10.3390/

horticulturae 8020095

Academic Editors: Begoña Miras-

Moreno and Esther Novo-Uzal

Received: 10 October 2021

Accepted: 11 January 2022

Published: 20 January 2022

Publisher's Note: MDPI stays neutral with regard to jurisdictional claims in published maps and institutional affiliations.

Copyright: (C) 2022 by the authors. Licensee MDPI, Basel, Switzerland. This article is an open access article distributed under the terms and conditions of the Creative Commons Attribution (CC BY) license (https:// creativecommons.org/licenses/by/ $4.0 /)$.
1 Escuela de Agronomía, Facultad de Ciencias, Universidad Mayor, Huechuraba 8580000, Chile; gaston.gutierrez@umayor.cl

2 Nutriprove, SA, Av. Linares 0410, La Granja 8780000, Chile; guerrero@nutriprove.com

3 Departamento de Ciencias Agrarias, Campus "San Isidro", Universidad Católica del Maule, km 6 Camino Los Niches, Curicó 3340000, Chile; marayaa@ucm.cl

4 Centro de Investigación Intihuasi, Instituto de Investigaciones Agropecuarias (INIA), Colina San Joaquín s/n, La Serena 1700000, Chile; nicolas.verdugo@inia.cl

5 Facultad de Ciencias Agrarias, Universidad de Talca, 2 Norte 685, Casilla 747, Talca 3460000, Chile

6 Departamento de Fruticultura y Enología, Pontificia Universidad Católica de Chile, Av. Vicuña Mackenna 4860, Macul 6904411, Chile

* Correspondence: hevaldes@uc.cl (H.V.-G.); cacevedo@utalca.cl (C.A.-O.); Tel.: +56-99-7766-7799 (H.V.-G.); +56-99-849-0066 (C.A.-O.)

\begin{abstract}
Background: Recently, antitranspirant or radiation-reflective products have been studied in several crops to mitigate the negative effects of global warming in Mediterranean climates. Nevertheless, to our knowledge, there is a scarce availability of information studying their effects on blueberries and much less from applications of sunscreens elaborated based on a mixture of dicarboxylic acids. Methods: Controls and three treatments were performed in 'Duke' and 'Star' blueberries as follows: (i) control without water stress (T1 $=100 \% \mathrm{ETc}$ ); (ii) foliar application of sunscreen in plants without water stress (T2 = 100\% ETc + sunscreen); (iii) water stress in plants without foliar application of sunscreen (T3 = 50\% ETc); (iv) foliar application of the sunscreen in plants with water stress (T4 $=50 \%$ ETc + sunscreen). Stem water potential ( $\Psi \mathrm{s})$, stomatal conductance $\left(g_{s}\right)$, yield, berry weight and berry total soluble solids were determined. (3) Results: As expected, the decrease in irrigation frequency in water stress treatments (T3 and T4) allowed for a decrease in the water applied at $25 \%$ compared to non-stressed plants (T1 and T2). This resulted in an increase in the $\Psi$ s on the days closest to harvest in both varieties, decreasing $g_{s}$ in blueberries plants subjected to water stress conditions. Sunscreen applications to Duke plants subjected to water stress (T4) induced higher total berry soluble solids than the treatments performed in non-stressed plants (T1 and T2). Sunscreen applications to Star plants subjected to water stress (T4) promoted similar $\mathrm{g}_{\mathrm{s}}$ levels and did not affect total soluble solids concerning irrigated plants (T1 and T2). (4) Conclusions: The results suggest that the response to water stress to sunscreen application based on dicarboxylic acid salts depended on the cultivar. Therefore, despite the novelty of this research, it is necessary to perform long-term studies to establish accurate conclusions.
\end{abstract}

Keywords: antitranspirants; global warming; highbush blueberry; Duke; Star

\section{Introduction}

Blueberry consumption has increased globally over the last years, mainly due to its high antioxidant potential because of its richness in phenolic compounds [1]. North America is a traditional market in which more than half of the fresh blueberries produced is consumed and their demand has considerably increased in new markets, such as Europe and China [2]. Based on this, traditional and new growth areas across the globe have 
increased blueberry production [3]. The highbush blueberry (Vaccinium corymbosum L.) presents a high fruit quality for fresh markets and a wide adaptation to subtropical and tropical production areas. This blueberry species is the most widely planted blueberry worldwide and is grown in different countries such as the United States, Canada, Perú, Mexico, Chile, Argentina, South Africa, Australia, New Zealand, Japan, China, and several European countries [4-6].

Most of the blueberry producing areas are characterized by significantly higher temperatures and solar radiation than the natural habitats in which blueberries grow [7]. Today, in the Mediterranean zones, there is a need to produce berries earlier in the season, which has forced growers to produce blueberries under high temperatures and solar radiation [8]. Blueberries are commercially harvested weekly for three to five or more weeks [9], which coincides with the period of greatest environmental stress in the season. It is important to highlight that erythemal UV irradiance in the southern hemisphere is up to $40 \%$ higher than in the northern hemisphere in summer [10]. Moreover, the expansion of highbush blueberry cultivation into warmer regions will be challenged in the future by global warming [5], making it necessary to adopt short-term adaption strategies to face these unfavourable productive conditions. Recently, the use of photo-selective color shading nets has been studied in blueberry production, allowing to mitigate the environmental stress conditions in open production orchards $[7,8]$. Shading nets have been shown to affect fruit yield and quality of blueberries, changing the harvest date towards cooler conditions $[7,8,11-13]$.

Antitranspirants and particle-film sprays have been used in several horticultural crops to mitigate environmental stress conditions, reducing sunburn, and improve fruit color [14-16]. However, to our knowledge, there are few studies about this subject in blueberries and much fewer regarding the application of dicarboxylic acids. Dicarboxylic acids and their derivatives are known to possess therapeutic properties and have been used in the treatment of a variety of skin disorders [17]. The application of these compounds in agriculture has allowed for an increases in their tolerance to biotic and abiotic stress [18,19]. Mono and disubstituted esters of dicarboxylic acids delayed plant growth and chlorophyll degradation [18]. Similar results have been found by Todorov et al. [19], who showed that monoesters of carboxylic acids retard plant growth and delay senescence processes by inhibiting chlorophyllase and peroxidase activities. In addition, these authors showed that dicarboxylic acids prolonged carbon assimilative activity and enhanced leaf wateruse efficiency in treated plants. In addition, dicarboxylic acid esters and salts have been used in plant disease prevention, retarding the infection of tomato leaves against different phytopathogens [20]. Therefore, the aim of this study was to evaluate the foliar application of a sunscreen elaborated by dicarboxylic acid salts on plant water status, gas exchange, productivity, and berry soluble solids in blueberries (V. corymbosum L. 'Duke', 'Star') plants, growing under Mediterranean conditions.

\section{Materials and Methods}

\subsection{Study Site and Plant Material}

An experimental trial was performed during the 2014 growing season in two full production plots of blueberries (Vaccinium corymbosum L. 'Duke' and 'Star') located in Botalcura, Pencahue, Maule Region (Chile), belonging to Círculo Agrícola ( $35^{\circ} 15^{\prime} \mathrm{S}, 71^{\circ} 47^{\prime} \mathrm{W}$, Datum WGS84, 77 m.a.s.l.). 'Duke' was established in 2008 and planted at $3.0 \mathrm{~m} \times 0.5 \mathrm{~m}$ spacing on sandy loam soil, while 'Star' was planted in 2010 at $3.0 \mathrm{~m} \times 1.0 \mathrm{~m}$. The plots were drip irrigated using one irrigation line per row with two emitters per plant spaced every $0.5 \mathrm{~m}$ supplying water at a rate of $2 \mathrm{~L} \mathrm{~h}^{-1}$. More information about the main characteristics of both plots is presented in Table 1 . 
Table 1. Main characteristic of 'Duke' and 'Star' orchards under study.

\begin{tabular}{ccc}
\hline Orchard Main Characteristics & Duke & Star \\
\hline Orchard age & 6 years old & 4 years old \\
Elevation & 76 & 77 \\
Spacing distance & $3.0 \times 0.5$ & $3.0 \times 1.0$ \\
Trellis system & Non-trellised & Non-trellised \\
Orientation & $330^{\circ}$ to Norwest & $30^{\circ}$ to Northeast \\
Irrigation system & Drip irrigation & Drip irrigation \\
\hline
\end{tabular}

\subsection{Soil and Climate Conditions}

The annual average temperature of Botacultura is $14.5^{\circ} \mathrm{C}$, with a minimum of $-2.5^{\circ} \mathrm{C}$ (in July) and a maximum of $36.7^{\circ} \mathrm{C}$ (in January), and an average annual rainfall of $658.8 \mathrm{~mm}$ (Figure 1). The orchard soil is clay loam, classified as Cunculen series, corresponding to the Alfisol order [21]. The soil is derived from a compacted sandstone in an intermediate remaining terrace position, presenting a flat to moderately undulating topography [21].

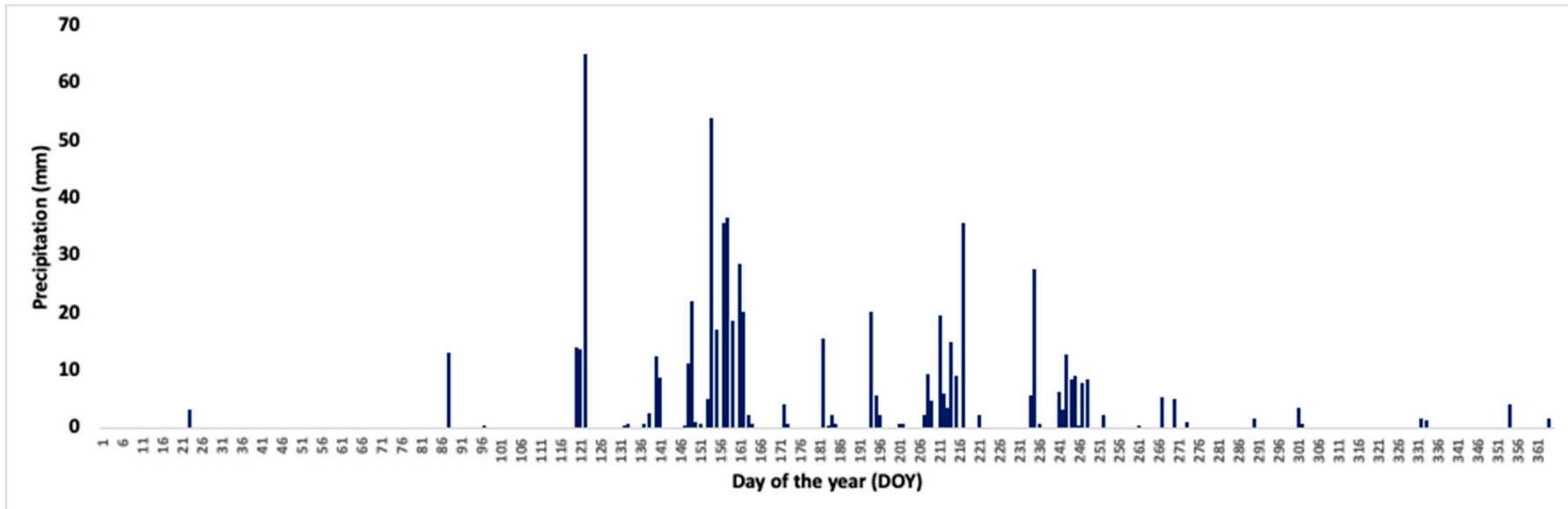

Figure 1. Annual accumulated precipitation ( $\mathrm{mm}$ ) of the blueberry (Vaccinium corymbosum L. 'Duke' and 'Star') plot.

\subsection{Experimental Design}

The experimental design was a randomized complete block divided into four treatments with four replicates, each consisting of sixteen plants per replicate. The irrigation treatments were based on crop evapotranspiration (ETc), as shown in Table 1. The treatments were managed with and without water stress. Therefore, the treatments were as follows: (i) control without water stress $(\mathrm{T} 1=100 \% \mathrm{ETc}$ ); (ii) foliar application of sunscreen in plants without water stress (T2 $=100 \%$ ETc + sunscreen); (iii) water stress in plants without foliar application of sunscreen (T3 $=50 \%$ ETc); (iv) foliar application of the sunscreen in plants with water stress (T4 $=50 \% \mathrm{ETc}+$ sunscreen). The sunscreen was developed based on a mixture of dicarboxylic acids. The selected plants evidenced good phytosanitary conditions and homogeneous vegetative growth and productivity. Table 2 shows the amount of water applied in the treatments by cultivar.

Foliar applications were performed using a sunscreen based on a mixture of dicarboxylic acids (OASIS ${ }^{\circledR}$, Nutriprove, Chile) applied at a dosage of $40 \mathrm{~g}$ per hectare of active ingredient, as recommended by the manufacturer. The product has a chemical formula of $\mathrm{HOOC}\left(\mathrm{CH}_{2}\right)_{\mathrm{n}} \mathrm{COOH}$; a molecular weight of 162.142 ; a concentration of $12 \%(w / w)$, i.e., $120 \mathrm{~g} \mathrm{~kg}^{-1}$; and a $\mathrm{pH}$ of 3.5. The treatments were performed in four foliar applications, in which the first was applied on 13 October (berry diameter: $10 \mathrm{~mm}$ ), the second on 28 October $(75 \%$ green $+25 \%$ pink fruit), the third on 11 November $(75 \%$ pink $+25 \%$ green fruit) and the last on 9 December (Ripe: $85-100 \%$ blue fruit). The blueberry stages were 
based on colour and fruit diameter. The product was sprayed with a manual spray pump calibrated prior to its use.

Table 2. Irrigation time and quantity of water applied in blueberry orchards under the growing season study for the 2014 season.

\begin{tabular}{ccc}
\hline $\begin{array}{c}\text { Water Applied According to } \\
\text { ETc and Variety }\end{array}$ & Sunscreen Application & Water Applied $\left(\mathbf{m}^{\mathbf{3}} \mathbf{h a}^{-\mathbf{1})}\right.$ \\
\hline $100 \%$ ETc in Duke & without & 2667 \\
$100 \%$ ETc in Star & with & 1600 \\
$50 \%$ ETc in Duke & without & 1334 \\
$50 \%$ Etc in Star & with & 800 \\
\hline
\end{tabular}

\subsection{Stem Water Potential and Stomatal Conductance Measurements}

Stem-water potential ( $\Psi$ s) was measured using a pressure chamber (PMS Instrument Co., model 600, Corvallis, OR, USA) according to the protocol outlined by Acevedo-Opazo et al. [22]. Briefly, two fully expanded and sun-exposed representative shoots per treatment were wrapped into a transparent plastic film and aluminium foil at least for two hours, thus achieving an equilibrium between leaf and plant xylem. The $\Psi$ s measurements were made between 12:00 and 14:00 h. During the study season, a total of six determinations were performed in Duke and eight in Star.

A leaf porometer model SC-1 (Decagon Devices, Pullman, WA, USA) was used to measure stomatal conductance $\left(\mathrm{g}_{\mathrm{s}}\right)$ in conditions of light saturation $\left(800 \mu \mathrm{mol} \mathrm{m} \mathrm{m}^{-2} \mathrm{~s}^{-1}\right.$ of photosynthetically active radiation). The $\mathrm{g}_{\mathrm{s}}$ determinations were performed between 12:00 and 14:00 $\mathrm{h}$ into five fully expanded and sun-exposed leaves per treatment.

\subsection{Yield, Berry Weight and Soluble Solids Measurements}

Blueberry harvest was performed twice in 'Duke' and 'Star' according to the procedures mentioned by other authors $[7,23,24]$. Berries were manually harvested from the replicates based on the external colour [23]. Immediately after, berries were weighed on a digital weight scale, recording yield by a plant $\left(\mathrm{kg} \mathrm{plant}^{-1}\right)$ and subsequently, berry weight was determined, taking randomly 100 berries per replicate. Total soluble solids from 25 fruits per replicate were measured from squeezed juice of every berry with a digital thermo-compensated refractometer (BRIX30 model, Leica IFT 40, Fisher Scientific, Waltham, MA, USA). The fruits were harvested twice from 2 to 11 December (2014).

\subsection{Statistical Analysis}

The statistical differences for the measured parameters were assessed using analysis of variance (ANOVA). Tukey test $(p \leq 0.05)$ was used for mean separation. A statistical analysis was performed using the Statgraphics Centurion XVI.I statistical package (Warrenton, VA, USA).

\section{Results}

\subsection{Stem Water Potential and Stomatal Conductance in Duke and Star Blueberries}

Table 3 shows stem-water potential ( $\Psi$ s) measured in Duke plants after the application of the treatments on six different dates. There were no statistical differences among the treatments and control in the first and the second measured dates. However, as expected, the treatments with water stress reached smaller $\Psi$ s than those without irrigation restrictions.

Table 4 shows stem-water potential ( $\Psi$ s) measured in Star plants after the application of the treatments on six different dates. There were no statistical differences among the treatments and control in the first, second, third and sixth measured dates. However, the treatments with water stress presented smaller $\Psi$ s in the fourth, fifth, seventh and eighth date than those without irrigation restrictions. 
Table 3. Stem water potential (MPa) measured in the performed treatments on 'Duke' along the season.

\begin{tabular}{ccccccc}
\hline Treatment (\% ETc) & 10 October & 24 October & 14 November & 21 November & 9 December & 12 December \\
\hline 100 (T1 control) & -0.43 & -0.66 & $-0.61 \mathrm{a}$ & $-0.66 \mathrm{a}$ & $-0.68 \mathrm{a}$ & $-0.59 \mathrm{a}$ \\
100 (T2 sunscreen) & -0.44 & -0.61 & $-0.61 \mathrm{a}$ & $-0.59 \mathrm{a}$ & $-0.66 \mathrm{a}$ & $-0.59 \mathrm{a}$ \\
50 (T3 control) & -0.52 & -0.61 & $-0.78 \mathrm{~b}$ & $-0.92 \mathrm{~b}$ & $-0.85 \mathrm{~b}$ & $-0.94 \mathrm{~b}$ \\
50 (T4 sunscreen) & -0.47 & -0.62 & $-0.81 \mathrm{~b}$ & $-0.89 \mathrm{~b}$ & $-0.90 \mathrm{~b}$ & $-1.04 \mathrm{~b}$ \\
Significance & N.S & N.S & $* *$ & $* *$ & $*$ & $*$ \\
\hline
\end{tabular}

For a given date, different letters within a column represent significant differences (Tukey's test, $p<0.05$ ) among the treatments (four replicates). ${ }^{*}$ Significant difference $(p<0.05)$. ${ }^{* *}$ Significant difference $(p<0.01)$. N.S: Not significant.

Table 4. Stem water potential (MPa) measured in the performed treatments on the 'Star' along the season.

\begin{tabular}{|c|c|c|c|c|c|c|c|c|}
\hline Treatment (\% ETc) & $\begin{array}{c}10 \\
\text { October }\end{array}$ & $\begin{array}{c}24 \\
\text { October }\end{array}$ & $\begin{array}{c}10 \\
\text { November }\end{array}$ & $\begin{array}{c}14 \\
\text { November }\end{array}$ & $\begin{array}{c}21 \\
\text { November }\end{array}$ & $\begin{array}{c}28 \\
\text { November }\end{array}$ & $\begin{array}{c}9 \\
\text { December }\end{array}$ & $\begin{array}{c}12 \\
\text { December }\end{array}$ \\
\hline 100 (T1 control) & -0.55 & -0.73 & -0.78 & $-0.81 \mathrm{a}$ & $-0.67 \mathrm{a}$ & -0.83 & $-0.63 \mathrm{ab}$ & $-0.75 \mathrm{a}$ \\
\hline 100 (T2 sunscreen) & -0.54 & -0.65 & -0.82 & $-0.85 a$ & $-0.67 \mathrm{a}$ & -0.81 & $-0.58 \mathrm{a}$ & $-0.76 \mathrm{a}$ \\
\hline 50 (T3 control) & -0.54 & -0.65 & -0.83 & $-0.93 \mathrm{ab}$ & $-0.83 b$ & -0.91 & $-0.74 b$ & $-0.96 \mathrm{~b}$ \\
\hline 50 (T4 sunscreen) & -0.53 & -0.66 & -0.80 & $-1.06 b$ & $-0.83 b$ & -1.01 & $-0.74 b$ & $-0.96 \mathrm{~b}$ \\
\hline Significance & N.S & N.S & N.S & $* *$ & $* *$ & N.S & $* *$ & * \\
\hline
\end{tabular}

For a given date, different letters within a column represent significant differences (Tukey's test, $p<0.05$ ) among the treatments (four replicates). ${ }^{*}$ Significant difference $(p<0.05) .{ }^{* *}$ Significant difference $(p<0.01)$. N.S Not significant.

Table 5 shows the stomatal conductance $\left(\mathrm{mol} \mathrm{H}_{2} \mathrm{O} \mathrm{m}^{-2} \mathrm{~s}^{-1}\right)$ measured in Duke and Star plants after applying the treatments. Treatments under water-stress induced lower stomatal conductance than the treatments without irrigation restriction in Duke plants. However, sunscreen applications in Star plants under water stress conditions induced higher stomatal conductance than the plants treated with water stress and did not show statistical differences compared to the control and sunscreen applications in Star plants without water stress.

Table 5. Stomatal conductance $\left(\mathrm{mol} \mathrm{H}_{2} \mathrm{O} \mathrm{m}^{-2} \mathrm{~s}^{-1}\right)$ measured on 12 December in the performed treatments on the Duke and Star cultivars.

\begin{tabular}{ccc}
\hline Treatment $(\%$ ETc) & Duke & Star \\
\hline 100 (T1 control) & $327.3 \mathrm{~b}$ & $288.4 \mathrm{~b}$ \\
$100(\mathrm{~T} 2$ sunscreen $)$ & $311.3 \mathrm{~b}$ & $276.8 \mathrm{~b}$ \\
50 (T3 control) & $204.9 \mathrm{a}$ & $122.0 \mathrm{a}$ \\
50 (T4 sunscreen) & $188.3 \mathrm{a}$ & $293.6 \mathrm{~b}$ \\
Significance & $*$ & $* *$
\end{tabular}

For a given variable, different letters within a column represent significant differences (Tukey's test, $p<0.05)$ among the treatments (four replicates). ${ }^{*}$ Significant difference $(p<0.05)$. ${ }^{* *}$ Significant difference $(p<0.01)$.

\subsection{Yield, Berry Weight and Berry Soluble Solids in Duke and Star Blueberries}

Table 6 shows the yield at first harvest and total yield in Duke and Star blueberries after the application of the treatments. There were no statistical differences among the treatments in total yield in 'Star' and 'Duke'. The yield at first harvest was not affected by the treatments in Duke. However, the treatments under water stress induced a higher yield at first harvest in Star plants than those without stress conditions.

Table 7 shows berry weight ( $\mathrm{g}$ ) at the first harvest in Duke and Star blueberries after applying the treatments. There were no statistical differences among the treatments in berry weight in Star and Duke cultivars. 
Table 6. Total yield and yield ( $\mathrm{g}_{\text {plant }}{ }^{-1}$ ) measured at the first harvest in the performed treatments on 'Duke' and 'Star'.

\begin{tabular}{ccccc}
\hline \multirow{2}{*}{ Treatment (\% ETc) } & \multicolumn{2}{c}{ Yield at First Harvest } & \multicolumn{2}{c}{ Total Yield } \\
\cline { 2 - 5 } & Duke & Star & Duke & Star \\
\hline 100 (T1 control) & 1512 & $1580 \mathrm{a}$ & 3287 & 3362 \\
$100($ T2 sunscreen) & 1631 & $1642 \mathrm{a}$ & 3136 & 3494 \\
50 (T3 control) & 1482 & $2352 \mathrm{~b}$ & 3221 & 3463 \\
50 (T4 sunscreen) & 1628 & $2360 \mathrm{~b}$ & 2961 & 3278 \\
Significance & N.S & $* *$ & N.S & N.S \\
\hline
\end{tabular}

For a given variable, different letters within a column represent significant differences (Tukey's test, $p<0.05$ ) among the treatments (four replicates). ${ }^{*}$ Significant difference $(p<0.01)$. N.S: Not significant.

Table 7. Berry weight $(\mathrm{g})$ measured at the first harvest of blueberry plants in the performed treatments on the Duke and Star cultivars.

\begin{tabular}{ccc}
\hline Treatment $(\%$ ETc) & Duke & Star \\
\hline 100 (T1 control) & 1.45 & 1.75 \\
$100($ T2 sunscreen) & 1.52 & 1.66 \\
50 (T3 control) & 1.41 & 1.71 \\
50 (T4 sunscreen) & 1.54 & 1.73 \\
Significance & N.S & N.S
\end{tabular}

For a given variable, different letters within a column represent significant differences (Tukey's test, $p<0.05$ ) among the treatments (four replicates). N.S: Not significant.

Table 8 shows berry soluble solids ( ${ }^{\circ}$ Brix) at the first and second harvest in Duke and Star blueberries after applying the treatments. Berry total soluble solids were not affected by the treatments in the Star cultivar. However, sunscreen applications in Duke plants managed under water stress-induced higher total soluble solids in berries than the control and sunscreen applications in plants without water restriction.

Table 8. Total soluble solids $\left({ }^{\circ}\right.$ Brix) at the first and second harvest of blueberry plants in the performed treatments on the Duke and Star cultivars.

\begin{tabular}{ccccc}
\hline \multirow{2}{*}{ Treatment (\% ETc) } & \multicolumn{2}{c}{ First Harvest } & \multicolumn{2}{c}{ Second Harvest } \\
\cline { 2 - 5 } & Duke & Star & Duke & Star \\
\hline 100 (T1 control) & $12.4 \mathrm{a}$ & 12.9 & $13.1 \mathrm{a}$ & 15.5 \\
100 (T2 sunscreen) & $12.3 \mathrm{a}$ & 12.7 & $13.5 \mathrm{ab}$ & 15.1 \\
50 (T3 control) & $12.7 \mathrm{ab}$ & 12.9 & $14.0 \mathrm{bc}$ & 15.7 \\
50 (T4 sunscreen) & $13.4 \mathrm{~b}$ & 12.7 & $14.2 \mathrm{c}$ & 15.9 \\
Significance & $*$ & N.S & $* *$ & N.S
\end{tabular}

For a given variable, different letters within a column represent significant differences (Tukey's test, $p<0.05$ ) among the treatments (four replicates). ${ }^{*}$ Significant difference $(p<0.05) .{ }^{*}$ Significant difference $(p<0.01)$. N.S: Not significant.

\section{Discussion}

As expected, the decrease in irrigation frequency in water stress treatments decreased the water applied by 50\% compared to the control. In addition, this allowed for a reduction in stem-water potential ( $\Psi$ s) on the days closest to harvest in both varieties and decreased stomatal conductance $\left(\mathrm{g}_{\mathrm{s}}\right)$ in blueberry plants (Tables 3-5). After the irrigation treatments had a statistically significant influence, Duke plants without irrigation restriction presented $\Psi$ s values from -0.6 to $-0.7 \mathrm{MPa}$ and the stressed plants reached $\Psi$ s from -0.8 to $-1.0 \mathrm{MPa}$. Under these same conditions, $\Psi$ s ranged from -0.6 to $-0,9$ in non-stressed plants and from -0.7 to $-1.1 \mathrm{MPa}$ in stressed plants in the Star cultivar. Different authors have reported similar results of $\Psi$ s after applying regulated deficit irrigation. Lobos et al. [25] reported -0.70 and $-1.20 \mathrm{MPa}$ in Brigitta plants for fully irrigated plants and severe water deficits, respectively. Keen and Slavich [26] described a range from -0.60 to $-1.50 \mathrm{MPa}$ in Star 
plants. Estrada et al. [27] measured -0.64 to $-1.29 \mathrm{MPa}$ as a mean for Bluegold, Elliott and Liberty cultivars. In this regard, some authors suggested that threshold values of $\Psi$ s $<1.0 \mathrm{MPa}$ can be used to avoid water stress, significant reductions in yield and berry quality in blueberries plants $[25,27,28]$.

Looking at the results, sunscreen based on dicarboxylic acid salts applications to blueberries (Vaccinium corymbosum L.) plants scarcely affected the $\Psi$ s in Duke and Star, but considerably maintained $\mathrm{g}_{\mathrm{s}}$ in Star plants managed under water stress conditions at the same level as irrigated plants (Table 5). Thus, concerning $\Psi$ s and $g_{s}$, there was no difference in the response of both cultivars. Severe water stress results in a low photosynthesis rate because stomatal conductance limits $\mathrm{CO}_{2}$ diffusion from the atmosphere to the leaves $[25,29]$. Regulated deficit irrigation treatments applied to Brigitta plants (50\% ETc) altered stomatal conductance and transpiration, reducing photosynthetic rate, stomatal conductance, and transpiration by 20 to $80 \%$ compared to control (100\% ETc) [25]. Midday stomatal conductance in different highbush blueberry cultivars decreased as the leaf water potential reached -0.6 to $-0.8 \mathrm{MPa}[30,31]$. Net photosynthesis and stomatal conductance reduced by $30 \%$ due to water stress resulting from no irrigation for three weeks at the onset of shoot growth compared to daily irrigation in Bluecrop blueberries [32]. In this fashion, sunscreen based on dicarboxylic acid salts applied to Star stressed plants allows for a maintenance of stomatal conductance levels such as in the fully irrigated plants.

Thermal and water stresses are increasingly frequent in the Mediterranean production area during summer, limiting productivity and berry quality $[8,33,34]$. The exogenous foliar application of radiation-reflecting products has proven effective in mitigating the negative impacts of these abiotic stresses in grapevine and other fruit crops [15,34-37]. However, to our knowledge, there is little available information about sunscreen foliar applications to mitigate thermal and water stress conditions in blueberries. Some authors have proposed that radiation-reflecting products could be used as additional tools to save water in several species, such as olives, clementine, tomatoes, and grapefruits [37-41]. However, there is an ongoing debate on its effects on gas exchanges, and mechanisms of action are not yet completely understood [35]. Some authors reported no effect or even an increase in net assimilation and stomatal conductance, while other researchers observed a reduction $[42,43]$. Based on this, the effectiveness of radiation-reflecting products in improving leaf resilience when subjected to severe environmental conditions, mainly through gas-exchange assessment, can be significantly changed according to the variety, water status, and stress severity [37]. The effects of these products suggest the modulation of indole-3-acetic acid (IAA), salicylic acid (SA), and abscisic acid (ABA) levels in crops cultivated in Mediterranean-type climates [37,44,45]. ABA is a growth regulator that controls stomatal closure, transpiration, and the plant's response to water stress and has been foliar-applied on apples with inconclusive results [46,47]. In this fashion, Frioni et al. [48] showed that leaves covered with kaolin (a radiation-reflecting inert product) had higher violaxanthin $(\mathrm{Vx})+$ antheraxanthin $(\mathrm{Ax})+$ zeaxanthin $(\mathrm{Zx})$ pool and a significantly lower neoxanthin $(\mathrm{Nx})$ content (VAZ) when water deficit became severe. Thus, kaolin allowed for the prevention of the ABA biosynthesis by avoiding the deviation of the VAZ epoxidation/de-epoxidation cycle into the ABA precursor biosynthetic direction. These authors suggested that the preservation of the active VAZ cycle and transpiration led to an improve in the dissipation of exceeding electrons, which explained the higher resilience of canopy functionality expressed by the application of kaolin.

A sunscreen based on dicarboxylic acid salts applications to Duke plants with managed under-water stress conditions produced berries with higher total soluble solids than those from non-stressed plants (Table 8). No different response of the two cultivars to treatments for yield and fruit weight was observed, and total soluble solids were slightly higher in plants subjected to water stress and sunscreen applications, probably because the yield was a little lower for this treatment than in the rest of the applications. To our knowledge, there is a scarce availability of information about the effects of dicarboxylic acid salts in horticulture. In general, dicarboxylic acids applications to crops allows for the hindering of plant growth 
and delays senescence processes by inhibiting chlorophyllase and peroxidase activities [19]. However, these results did not coincide those found in this manuscript. Currently, the study of the applications of radiation-reflecting products, mainly of kaolin, has increased, especially in viticulture and vegetable production [37,42]. Kaolin foliar applications to grapevines decreased berry sugar content without affecting malic and tartaric acid levels and reactive oxygen species accumulation throughout berry ripening [37]. Most of the authors agreed that kaolin exerts a delaying effect in triggering ripening-related processes under severe summer stress conditions $[33,37,49]$. However, the application in tomato may or may not improve the accumulation of total soluble solids under salinity and water stress conditions, improving water use efficiency $[42,50]$. Therefore, under water stress conditions, sunscreen based on dicarboxylic acid salts applications to Duke increased berry total soluble solids in comparison to its application to non-stressed plants. Moreover, this treatment, when applied to Star blueberries, maintained stomatal conductance at the same level as irrigated plants.

Diurnal changes in gs, $\Psi$ s and transpiration have been reported to be closely related in blueberries [31]. Regardless of cultivar, gs decreases quickly as $\Psi$ s reaches close to $-0.6 \mathrm{MPa}$ [51]. Byers et al. [52] showed that the root system of highbush blueberries is inefficient in water uptake, even if soils water soil levels are adequate. There is a scarce availability of information in the scientific literature regarding the response to drought or heat stress by blueberries plants. 'Duke' maintained lower $\Psi$ s and higher gs than 'Elliott' and 'Bluecrop' as soil water was depleted [51]. This may indicate that this cultivar has the highest tolerance for short-term soil water deficits [51]. In this fashion, Bryla and Strik [31] suggested that 'Duke' might require a lower irrigation frequency than the other cultivars since it develops a deep-root system and extracts more water at depths below $0.6 \mathrm{~m}$. No further evidence was found in the literature about the response of Star to drought or heat stress.

Based on these preliminary results, it is necessary to perform long-term studies accounting for more factors and variables, such as $\mathrm{CO}_{2}$ assimilation and water use efficiency, among others, to establish accurate conclusions related to the application of dicarboxylic acid salts to blueberries.

Author Contributions: Conceptualization, M.G.-M., M.A.-A., N.V.-V., H.V.-G. and C.A.-O.; methodology, M.G.-M., H.V.-G. and C.A.-O.; software, G.G.-G., M.G.-M., M.A.-A. and N.V.-V.; validation, M.G.-M., H.V.-G. and C.A.-O.; resources, M.G.-M., H.V.-G. and C.A.-O.; data curation, M.G.-M., M.A.-A. and N.V.-V.; writing-original draft preparation, G.G.-G., M.G.-M., M.A.-A. and N.V.-V.; writing-review and editing, M.A.-A., N.V.-V., H.V.-G. and C.A.-O.; supervision, H.V.-G. and C.A.-O.; project administration, H.V.-G. and C.A.-O.; funding acquisition, M.G.-M., H.V.-G. and C.A.-O. All authors have read and agreed to the published version of the manuscript.

Funding: This research received no external funding.

Institutional Review Board Statement: Not applicable.

Informed Consent Statement: Not applicable.

Acknowledgments: The authors would like to thank Samuel Ortega-Farias and all the technical staff of CITRA-UTALCA for providing the leaf porometer. The authors also would like to thank to Círculo Agrícola represented by Eduardo Engber, and to Nutriprove S.A represented by Hermann Frigerio, for their important contribution to the development of this research.

Conflicts of Interest: The authors declare no conflict of interest.

\section{References}

1. Može, Š.; Polak, T.; Gašperlin, L.; Koron, D.; Vanzo, A.; Ulrih, N.P.; Abram, V. Phenolics in Slovenian bilberries (Vaccinium myrtillus L.) and blueberries (Vaccinium corymbosum L.). J. Agric. Food Chem. 2011, 59, 6998-7004. [CrossRef]

2. Brazelton, C.; Fain, C.; Aragon, L.; Bauer, N. IBO 2019 State of the Blueberry Industry Report. Available online: https://www. internationalblueberry.org/downloads / online-visualization/ (accessed on 26 July 2021). 
3. Fang, Y.; Nunez, G.H.; da Silva, M.N.; Phillips, D.A.; Munoz, P.R. A review for southern highbush blueberry alternative production systems. Agronomy 2020, 10, 1531. [CrossRef]

4. Strik, B.C.; Yarborough, D. Blueberry production trends in North America, 1992 to 2003, and predictions for growth. Horttechnology 2005, 15, 391-398. [CrossRef]

5. Lobos, G.A.; Hancock, J.F. Breeding blueberries for a changing global environment: A review. Front. Plant Sci. $2015,6,782$. [CrossRef]

6. $\quad$ Retamales, J.B.; Palma, M.J.; Morales, Y.A.; Lobos, G.A.; Moggia, C.E.; Mena, C.A. Blueberry production in Chile: Current status and future developments. Rev. Bras. Frutic. 2014, 36, 58-67. [CrossRef]

7. Lobos, G.A.; Retamales, J.B.; Hancock, J.F.; Flore, J.A.; Romero-Bravo, S.; Del Pozo, A. Productivity and fruit quality of Vaccinium corymbosum cv. Elliott under photo-selective shading nets. Sci. Hortic. 2013, 153, 143-149. [CrossRef]

8. Retamales, J.B.; Montecino, J.M.; Lobos, G.A.; Rojas, L.A. Colored shading nets increase yields and profitability of highbush blueberries. Acta Hortic. 2008, 770, 193-197. [CrossRef]

9. Zorenc, Z.; Veberic, R.; Stampar, F.; Koron, D.; Petkovsek Mikulic, M. Changes in berry quality of northern highbush blueberry (Vaccinium corymbosum L.) during the harvest season. Turk. J. Agric. For. 2016, 40, 855-864. [CrossRef]

10. Madronich, S.; McKenzie, R.L.; Björn, L.O.; Caldwell, M.M. Changes in biologically active ultraviolet radiation reaching the Earth's surface. J. Photochem. Photobiol. B Biol. 1998, 46, 5-19. [CrossRef]

11. Kim, S.J.; Yu, D.J.; Kim, T.C.; Lee, H.J. Growth and photosynthetic characteristics of blueberry (Vaccinium corymbosum cv. Bluecrop) under various shade levels. Sci. Hortic. 2011, 129, 486-492. [CrossRef]

12. Rodríguez Beraud, M.M.; Morales Ulloa, D.M. Shading nets effect on the production and quality of blueberry fruit (Vaccinium corymbosum L.) cv. Brigitta. Sci. Agropecu. 2015, 6, 41-50. [CrossRef]

13. Zoratti, L.; Jaakola, L.; Häggman, H.; Giongo, L. Modification of sunlight radiation through colored photo-selective nets affects anthocyanin profile in Vaccinium spp. berries. PLoS ONE 2015, 10, e0135935. [CrossRef] [PubMed]

14. Palliotti, A.; Panara, F.; Famiani, F.; Sabbatini, P.; Howell, G.S.; Silvestroni, O.; Poni, S. Postveraison application of antitranspirant di-1-p-menthene to control sugar accumulation in sangiovese grapevines. Am. J. Enol. Vitic. 2013, 64, 378-385. [CrossRef]

15. Spiers, J.D.; Matta, F.B.; Marshall, D.A. Effects of kaolin clay particle film on southern highbush (Vaccinium corymbosum L.) blueberry plants. Small Fruit Rev. 2008, 2, 29-36. [CrossRef]

16. Spiers, J.D.; Matta, F.B.; Sampson, B.J. Impact of kaolin particle films on the abundance of flower thrips, Frankliniella spp. (Thysanoptera: Thripidae) associated with rabbiteye blueberry (Vaccinium ashei reade). Acta Hortic. 2003, 626, 207-212. [CrossRef]

17. Nazzaro-Porro, M. Azelaic acid. J. Am. Acad. Dermatol. 1987, 17, 1033-1041. [CrossRef]

18. Aleksieva, V.S.; Karanov, E.N. Growth retardant activity of certain aliphatic dicarboxylic acids and their diethyl esters. Compt. Rend. Acad. Bulg. Sci. 1987, 40, 85-88.

19. Todorov, D.; Alexieva, V.; Karanov, E.; Velichkov, D.; Velikova, V. Effect of certain dicarboxylic acid monoesters on growth, chlorophyll content, chlorophyllase and peroxidase activities, and gas-exchange of young maize plants. J. Plant Growth Regul. 1992, 11, 233-238. [CrossRef]

20. Flors, V.; Miralles, M.C.; Varas, E.; Company, P.; González-Bosch, C.; García-Agustín, P. Effect of analogues of plant growth regulators on in vitro growth of eukaryotic plant pathogens. Plant Pathol. 2004, 53, 58-64. [CrossRef]

21. Gutiérrez-Gamboa, G.; Garde-Cerdán, T.; Gonzalo-Diago, A.; Moreno-Simunovic, Y.; Martínez-Gil, A.M. Effect of different foliar nitrogen applications on the must amino acids and glutathione composition in Cabernet Sauvignon vineyard. LWT-Food Sci. Technol. 2017, 75, 147-154. [CrossRef]

22. Acevedo-Opazo, C.; Valdés-Gómez, H.; Taylor, J.A.; Avalo, A.; Verdugo-Vásquez, N.; Araya, M.; Jara-Rojas, F.; Tisseyre, B. Assessment of an empirical spatial prediction model of vine water status for irrigation management in a grapevine field. Agric. Water Manag. 2013, 124, 58-68. [CrossRef]

23. Moggia, C.; Graell, J.; Lara, I.; Schmeda-Hirschmann, G.; Thomas-Valdés, S.; Lobos, G.A. Fruit characteristics and cuticle triterpenes as related to postharvest quality of highbush blueberries. Sci. Hortic. 2016, 211, 449-457. [CrossRef]

24. Lobos, T.E.; Retamales, J.B.; Hanson, E.J. Early preharvest calcium sprays improve postharvest fruit quality in 'Liberty' highbush blueberries. Sci. Hortic. 2021, 277, 109790. [CrossRef]

25. Lobos, T.E.; Retamales, J.B.; Ortega-Farías, S.; Hanson, E.J.; López-Olivari, R.; Mora, M.L. Regulated deficit irrigation effects on physiological parameters, yield, fruit quality and antioxidants of Vaccinium corymbosum plants cv. Brigitta. Irrig. Sci. 2018, 36, 49-60. [CrossRef]

26. Keen, B.; Slavich, P. Comparison of irrigation scheduling strategies for achieving water use efficiency in highbush blueberry. N. Z J. Crop Hortic. Sci. 2012, 40, 3-20. [CrossRef]

27. Estrada, F.; Escobar, A.; Romero-Bravo, S.; González-Talice, J.; Poblete-Echeverría, C.; Caligari, P.D.S.; Lobos, G.A. Fluorescence phenotyping in blueberry breeding for genotype selection under drought conditions, with or without heat stress. Sci. Hortic. 2015, 181, 147-161. [CrossRef]

28. Ortega-Farias, S.; Espinoza-Meza, S.; López-Olivari, R.; Araya-Alman, M.; Carrasco-Benavides, M. Effects of different irrigation levels on plant water status, yield, fruit quality, and water productivity in a drip-irrigated blueberry orchard under Mediterranean conditions. Agric. Water Manag. 2021, 249, 106805. [CrossRef] 
29. Gutiérrez-Gamboa, G.; Pérez-Donoso, A.G.; Pou-Mir, A.; Acevedo-Opazo, C.; Valdés-Gómez, H. Hydric behaviour and gas exchange in different grapevine varieties (Vitis vinifera L.) from the Maule Valley (Chile). S. Afr. J. Enol. Vitic. 2019, 40, 181-191. [CrossRef]

30. Bryla, D.R.; Strik, B.C. Effects of cultivar and plant spacing on the seasonal water requirements of highbush blueberry. J. Am. Soc. Hortic. Sci. 2007, 132, 270-277. [CrossRef]

31. Bryla, D.R.; Strik, B.C. Variation in plant and soil water relations among irrigated blueberry cultivars planted at two distinct in-row spacings. Acta Hortic. 2006, 715, 295-300. [CrossRef]

32. Rho, H.; Yu, D.J.; Kim, S.J.; Lee, H.J. Limitation factors for photosynthesis in 'Bluecrop' highbush blueberry (Vaccinium corymbosum) leaves in response to moderate water stress. J. Plant Biol. 2013, 55, 450-457. [CrossRef]

33. Gutiérrez-Gamboa, G.; Zheng, W.; Martínez de Toda, F. Current viticultural techniques to mitigate the effects of global warming on grape and wine quality: A comprehensive review. Food Res. Int. 2021, 139, 109946. [CrossRef] [PubMed]

34. Conde, A.; Pimentel, D.; Neves, A.; Dinis, L.-T.; Bernardo, S.; Correia, C.M.; Gerós, H.; Moutinho-Pereira, J. Kaolin foliar application has a stimulatory effect on phenylpropanoid and flavonoid pathways in grape berries. Front. Plant Sci. 2016, 7, 1150. [CrossRef]

35. Brillante, L.; Belfiore, N.; Gaiotti, F.; Lovat, L.; Sansone, L.; Poni, S.; Tomasi, D. Comparing kaolin and pinolene to improve sustainable grapevine production during drought. PLoS ONE 2016, 11, e0156631. [CrossRef]

36. Dinis, L.-T.; Bernardo, S.; Matos, C.; Malheiro, A.; Flores, R.; Alves, S.; Costa, C.; Rocha, S.; Correia, C.; Luzio, A.; et al. Overview of kaolin outcomes from vine to wine: Cerceal white variety case study. Agronomy 2020, 10, 1422. [CrossRef]

37. Bernardo, S.; Dinis, L.-T.; Machado, N.; Barros, A.; Pitarch-Bielsa, M.; Malheiro, A.C.; Gómez-Cadenas, A.; Moutinho-Pereira, $\mathrm{J}$. Uncovering the effects of kaolin on balancing berry phytohormones and quality attributes of Vitis vinifera grown in warmtemperate climate regions. J. Sci. Food Agric. 2022, 102, 782-793. [CrossRef]

38. Boari, F.; Donadio, A.; Schiattone, M.I.; Cantore, V. Particle film technology: A supplemental tool to save water. Agric. Water Manag. 2015, 147, 154-162. [CrossRef]

39. Jifon, J.L.; Syvertsen, J.P. Kaolin particle film applications can increase photosynthesis and water use efficiency of 'Ruby Red' grapefruit leaves. J. Am. Soc. Hortic. Sci. 2003, 128, 107-112. [CrossRef]

40. Oliveira da Silva, P.S.; de Oliveira Alves Sena, E.; Silva Gonzaga, M.I.; Ganassali de Oliveira, L.F.; dos Santos Maciel, L.B.; Pinheiro Fiaes dos Santos, M.; Costa de Mattos, E.; Lima Dias, K.L.; Botelho Carneiro, R.; Gutierrez Carnelossi, M.A. Calcium carbonate particle films and water regimes affect the acclimatization, ecophysiology and reproduction of tomato. Environ. Exp. Bot. 2019, 165, 19-29. [CrossRef]

41. Brito, C.; Gonçalves, A.; Silva, E.; Martins, S.; Pinto, L.; Rocha, L.; Arrobas, M.; Rodrigues, M.Â.; Moutinho-Pereira, J.; Correia, C.M. Kaolin foliar spray improves olive tree performance and yield under sustained deficit irrigation. Sci. Hortic. 2021, $277,109795$. [CrossRef]

42. Cantore, V.; Pace, B.; Albrizio, R. Kaolin-based particle film technology affects tomato physiology, yield and quality. Environ. Exp. Bot. 2009, 66, 279-288. [CrossRef]

43. Moftah, A.E.; Al Humaid, A.I. Effects of Kaolin and Pinolene film-forming polymers on water relations and photosynthetic rate of tuberose (Polianthes tuberosa L.) plants under water deficit conditions. J. Appl. Hortic. 2004, 06, 16-22. [CrossRef]

44. Bernardo, S.; Dinis, L.-T.; Luzio, A.; Machado, N.; Gonçalves, A.; Vives-Peris, V.; Pitarch-Bielsa, M.; López-Climent, M.F.; Malheiro, A.C.; Correia, C.; et al. Optimising grapevine summer stress responses and hormonal balance by applying kaolin in two Portuguese Demarcated Regions. OENO One 2021, 55, 207-222. [CrossRef]

45. Dinis, L.T.; Bernardo, S.; Luzio, A.; Pinto, G.; Meijón, M.; Pintó-Marijuan, M.; Cotado, A.; Correia, C.; Moutinho-Pereira, J. Kaolin modulates ABA and IAA dynamics and physiology of grapevine under Mediterranean summer stress. J. Plant Physiol. 2018, 220, 181-192. [CrossRef]

46. Iamsub, K.; Sekozawa, Y.; Sugaya, S.; Gemma, H.; Kamuro, Y. Alleviating sunburn injury in apple fruit using natural and fertilizer forms of S-abscisic acid and its underlying mechanism. J. Food Agric. Environ. 2009, 7, 446-452.

47. Gambetta, J.M.; Holzapfel, B.P.; Stoll, M.; Friedel, M. Sunburn in grapes: A review. Front. Plant Sci. 2021, 11, 604691. [CrossRef] [PubMed]

48. Frioni, T.; Tombesi, S.; Sabbatini, P.; Squeri, C.; Rodas, N.L.; Palliotti, A.; Poni, S. Kaolin reduces ABA biosynthesis through the inhibition of neoxanthin synthesis in grapevines under water deficit. Int. J. Mol. Sci. 2020, 21, 4950. [CrossRef] [PubMed]

49. Palliotti, A.; Tombesi, S.; Silvestroni, O.; Lanari, V.; Gatti, M.; Poni, S. Changes in vineyard establishment and canopy management urged by earlier climate-related grape ripening: A review. Sci. Hortic. 2014, 178, 43-54. [CrossRef]

50. Boari, F.; Donadio, A.; Pace, B.; Schiattone, M.I.; Cantore, V. Kaolin improves salinity tolerance, water use efficiency and quality of tomato. Agric. Water Manag. 2016, 167, 29-37. [CrossRef]

51. Retamales, J.B.; Hancock, J.F. Blueberries. Crop Production Science in Horticulture 21; CABI: Wallingford, UK, 2012.

52. Byers, P.L.; Moore, J.N.; Scott, H.D. Plant-water relations of young highbush blueberry plants. HortScience 1988, $23,870-873$. 